\title{
EFFECTS OF DIFFERENT DRYING METHODS ON COMPONENTS OF THYMBRA SPICATA L. ESSENTIAL OIL FROM FLORA OF HATAY (TURKEY)
}

\author{
AHMET MERT, MUSA TÜRKMEN, NAD RE PELIN BAHADIRLI, DURMUS ALPASLAN \\ KAYA, FILIZ AYANOĞLU, ŞEVKET ÖZTURK \\ Mustafa Kemal University, Faculty of Agriculture, 31030, Antakya-Hatay, Turkey
}

\begin{abstract}
Zahter (Thymbra spicata), a perennial member of the Labiatae family is one of the most important spices in Hatay's cuisine. Its dry leaves are mixed with red pepper, sesame and çökelek (a special cheese in the region) and is heavily used in sürk (a dish made with çökelek) and pastries. This study aims to determine the effects of various drying methods on the essential oil content of thymbra spicata, a naturally growing plat in Hatay. The plant material was harvested from Hatay's flora on May 4, 2015 and dried in the shade, in an oven at $30^{\circ} \mathrm{C}$. The essential oil was obtained with vapor distillation, and its contents were determined using GC/MS. The study determined that the ratio of carvacrol, the main component off Thymbra spicata essential oil changes between $\% 51.14$ and 72.54 .
\end{abstract}

Keywords: Thymbra, Drying, GC-MS

\section{INDRODUCTION}

Zahter (Thymbra spicata) is a member of the Labiatae family and is spread around the Eastern Mediterranean countries. In our country, it is widely found in the Thracian, Aegean, Mediterranean coasts and the South-Eastern Anatolia region. Thymbra spicata is an evergreen shrub that is approximately $50 \mathrm{~cm}$ high (Kız1 et al., 2009). Its essential oil content is reported to vary between 4.016 and $4.700 \%$ (Mert and Türkmen, 2015). 70-80\% of T. spicata essential oil consists of Carvacrol (Kizıl et al., 2009). Zahteri (Thymbra spicata) has an economic value in Antakya region. About 10-12 tons of thyme is sold every year (Dağıstan and Sarıhan, 2000). Thyme is one of the famous spices in Hatay cuisine. Fresh Thymbra spicata is basically used to make salad. Dry leaves were mixed with pepper, sesame amd cokelek to wake surk and bakery products. Thyme tea is popular drunk in houses and cafes (Mert and Ark, 2007).

This study aims to determine the effects of various drying methods on the essential oil content of Thymbra spicata, a naturally growing plat in Hatay.

\section{MATERIALS AND METHODS}

\section{Materials}

The plant materials were collected from Hatay floara on May 4, 2015.

\section{Methods}

Thyme leaves treated with different drying methods which is given below. Treatments:

- At shade

- At sunshine

- At $30^{\circ} \mathrm{C}$ temperature in the oven 
Effects of Different Drying Methods on Components of Thymbra spicata L.

Essential Oil from Flora of Hatay (Turkey)

(Dry leaves were used for extrection of essential oil of thyme leaves with water steam distilation (Neo-Clevenger) in each treatment.)

\section{Gas Chromatography - Mass Spectrometry (GC-MS)}

The components of the Thymbra spicata essential oils used in the study were determined using gas chromatography-mass spectrometry in the Medical and Aromatic Plants Analysis Laboratory of the Mustafa Kemal University Faculty of Agriculture Department of Field Crops. The identification of essential oil components was made using a Thermo Scientific ISQ Single Quadrupole gas chromatography device; using TG-Wax WS model (5\% Phenyl Polysilphenylene-siloxane, $0,25 \mathrm{~mm}$ internal diameter * $30 \mathrm{~m}$ length, $0.25 \mu \mathrm{m}$ film thickness) column. The ionization energy was set to $70 \mathrm{eV}$ and the mass interval $\mathrm{m} / \mathrm{z}$ was set to $1.2-1200$. Scan mode was used for data collection. MS transfer line temperature was $250{ }^{\circ} \mathrm{C}$, MS ionization temperature was $220{ }^{\circ} \mathrm{C}$, column temperature was initially $50{ }^{\circ} \mathrm{C}$ and increased to $220{ }^{\circ} \mathrm{C}$ with $3{ }^{\circ} \mathrm{C} /$ minute increments. The structure of ech compound was identified by the Xcalibur software using mass spectra (Wiley 9).

\section{RESULTS AND DISCUSSION}

The components and component ratios of the essential oil obtained from the Thymbra spicata plant naturally growing in Hatay are presented in Table 1. As evidenced in Table 1, the main component, Carvacrol constitutes $72.54 \%$ of the essential oil, and is followed by $\gamma$-Terpinene with $17.18 \%$ and o-Cymene with $\% 4.90$.

Table 1. The components and component ratios of the essential oil obtained from the Thymbra spicata plant naturally growing in Hatay

\begin{tabular}{llll}
\hline RT & Compound Name & Cas \# & Area \% \\
\hline 3,43 & $\alpha$-Pinene & $80-56-8$ & 0.10 \\
3,48 & $\alpha$-Thujene & $99-83-2$ & 0.15 \\
5,07 & $\beta$-Phellandrene & $555-10-2$ & 0.06 \\
6,05 & $\beta$-Myrcene & $123-35-3$ & 0.35 \\
6,4 & $\alpha$-Terpinene & $99-86-5$ & 0.60 \\
6,88 & 1-Limonene & $5989-54-8$ & 0.09 \\
7,08 & Eucalyptol & $470-82-6$ & 0.34 \\
8,22 & $\gamma$-Terpinene & $99-85-4$ & 17.18 \\
9,01 & o-Cymene & $527-84-4$ & 4.90 \\
15,43 & 1-Octen-3-ol & $3391-86-4$ & 0.10 \\
15,82 & trans Sabinene hydrate & $17699-16-0$ & 0.08 \\
17,46 & cis-Limonene oxide & $13837-75-7$ & 0.12 \\
20,39 & trans-Caryophyllene & $87-44-5$ & 0.72 \\
20,9 & Terpinen-4-ol & $562-74-3$ & 0.14 \\
24,47 & Isoborneol & $124-76-5$ & 0.11 \\
33,48 & (-)-Caryophyllene oxide & $1139-30-6$ & 0.12 \\
34,38 & $\alpha-S i n e n s a l$ & $17909-77-2$ & 0.06 \\
38,55 & (+) spathulenol & $77171-55-2$ & 0.29 \\
40,45 & Thymol & $89-83-8$ & 0.09 \\
41,7 & Carvacrol & $499-75-2$ & 72.54 \\
50,56 & Cyclohexene, 2-ethenyl-1,3,3-trimethyl- & $5293-90-3$ & 0.16 \\
51,12 & 3,5-Heptadienal, 2-ethylidene-6-methyl- & $99172-18-6$ & 0.09 \\
\hline
\end{tabular}


ICAMS $2016-6^{\text {th }}$ International Conference on Advanced Materials and Systems

The components and component ratios of the essential oil obtained from the shadedried leaves of Thymbra spicata that grows naturally in Hatay are presented in table 2. As evidenced in table 2, the main component Carvacrol is present at $58.32 \%$ and is followed by $\gamma$-Terpinene at $28.53 \%$ and $5.20 \%$ with o-Cymene.

Table 2. The components and component ratios (\%) of the essential oil obtained from the shade-dried leaves of the Thymbra spicata plant naturally growing in Hatay

\begin{tabular}{llll}
\hline RT & Compound Name & Cas \# & Area \% \\
\hline 3,42 & $\alpha$-Pinene & $80-56-8$ & 0.30 \\
3,48 & $\alpha$-Thujene & $2867-05-2$ & 1.05 \\
4,79 & $\beta$-Pinene & $127-91-3$ & 0.08 \\
5,07 & Sabinene & $3387-41-5$ & 0.11 \\
6,05 & $\beta$-Myrcene & $123-35-3$ & 0.96 \\
6,4 & $\alpha$-Terpinene & $99-86-5$ & 2.03 \\
6,88 & Limonene & $5989-54-8$ & 0.14 \\
7,07 & Eucalyptol & $470-82-6$ & 0.06 \\
7,13 & $\beta$-Phellandrene & $555-10-2$ & 0.11 \\
8,23 & $\gamma$-Terpinene & $99-85-4$ & 28.53 \\
9,01 & o-Cymene & $527-84-4$ & 5.20 \\
18,91 & trans Sabinene hydrate & $17699-16-0$ & 0.06 \\
20,39 & trans-Caryophyllene & $87-44-5$ & 1.26 \\
20,9 & Terpinen-4-ol & $562-74-3$ & 0.11 \\
24,46 & L- $\alpha$-Terpineol & $10482-56-1$ & 0.08 \\
33,75 & Caryophyllene oxide & $1139-30-6$ & 0.23 \\
38,54 & (+) spathulenol & $77171-55-2$ & 0.23 \\
40,92 & Thymol & $89-83-8$ & 0.12 \\
41,7 & Carvacrol & $89-83-8$ & 58.32 \\
50,56 & 3,5-Heptadienal, 2-ethylidene-6-methyl- & $99172-18-6$ & 0.08 \\
\hline
\end{tabular}

The components and component ratios of the essential oil obtained from the sun dried leaves of Thymbra spicata plant naturally growing in Hatay are presented in Table 3. As evidenced in Table 3, the main component, Carvacrol constitutes $51.14 \%$ of the essential oil, and is followed by $\gamma$-Terpinene with $23.38 \%, \alpha$-Terpinyl at $7.45 \%$ and oCymene at \% 3.86. 
Effects of Different Drying Methods on Components of Thymbra spicata L. Essential Oil from Flora of Hatay (Turkey)

Table 3. The components and component ratios (\%) of the essential oil obtained from the sun-dried leaves of the Thymbra spicata plant naturally growing in Hatay

\begin{tabular}{|c|c|c|c|}
\hline RT & Compound Name & Cas \# & Area \% \\
\hline 3,41 & $\alpha$-Pinene & $80-56-8$ & 0.20 \\
\hline 3,47 & $\alpha$-Thujene & $2867-05-2$ & 0.67 \\
\hline 4,04 & Camphene & $79-92-5$ & 0.07 \\
\hline 4,76 & $\beta$-Pinene & $127-91-3$ & 0.07 \\
\hline 5,04 & Sabinene & $3387-41-5$ & 0.08 \\
\hline 6,01 & $\beta$-Myrcene & $123-35-3$ & 0.68 \\
\hline 6,36 & $\alpha$-Terpinene & $99-86-5$ & 1.50 \\
\hline 6,85 & Limonene & $5989-54-8$ & 0.11 \\
\hline 7,04 & Eucalyptol & $470-82-6$ & 0.11 \\
\hline 7,1 & $\beta$-Phellandrene & $555-10-2$ & 0.07 \\
\hline 8,19 & $\gamma$-Terpinene & $99-85-4$ & 23.38 \\
\hline 8,97 & o-Cymene & $527-84-4$ & 3.86 \\
\hline 14,03 & Thujone & $546-80-5$ & 0.06 \\
\hline 14,12 & cis Sabinene hydrate & $17699-16-0$ & 0.16 \\
\hline 15,41 & 1-Octen-3-ol & $3391-86-4$ & 0.07 \\
\hline 17,38 & Camphor & $76-22-2$ & 0.12 \\
\hline 17,89 & trans Sabinene hydrate & $17699-16-0$ & 0.18 \\
\hline 18,28 & Linalool & $78-70-6$ & 0.34 \\
\hline 18,51 & 1-Terpinenol & $586-82-3$ & 0.07 \\
\hline 20,14 & Terpinen-4-ol & $562-74-3$ & 1.61 \\
\hline 20,38 & trans-Caryophyllene & $87-44-5$ & 1.03 \\
\hline 22,2 & trans-Pinocarveol & $547-61-5$ & 0.15 \\
\hline 23,06 & $\alpha$-Terpineol & $98-55-5$ & 0.28 \\
\hline 23,85 & $\alpha$-Terpinyl acetate & $80-26-2$ & 7.45 \\
\hline 24,07 & L- $\alpha$-Terpineol & 10482-56-1 & 1.66 \\
\hline 24,47 & Borneol, acetate & $5655-61-8$ & 0.08 \\
\hline 25,43 & Limonene oxide & $1195-92-2$ & 0.12 \\
\hline 27,57 & Myrtenol & $515-00-4$ & 0.09 \\
\hline 27,82 & p-Mentha-1(7),8-dien-2-ol & $35907-10-9$ & 0.07 \\
\hline 33,65 & (-)-Caryophyllene oxide & $1139-30-6$ & 0.37 \\
\hline 35,4 & Anisylacetone & $104-20-1$ & 1.09 \\
\hline 38,53 & (-)-Spathulenol & $77171-55-2$ & 0.39 \\
\hline 39,55 & Acetic acid, cinnamyl ester & $103-54-8$ & 0.08 \\
\hline 40,1 & Eugenol & $97-53-0$ & 0.22 \\
\hline 40,92 & Thymol & $89-83-8$ & 0.13 \\
\hline 41,41 & Junipene & $475-20-7$ & 0.07 \\
\hline 41,71 & Carvacrol & $499-75-2$ & 51.14 \\
\hline 45,12 & Alloaromadendrenoxıd-(1) & $85710-39-0$ & 0.06 \\
\hline
\end{tabular}

The components and component ratios of the essential oil obtained from the leaves dried in a $30^{\circ} \mathrm{C}$ oven of Thymbra spicata plant naturally growing in Hatay are presented in Table 4. As evidenced in Table 4, the main component, Carvacrol constitutes $60.33 \%$ of the essential oil, and is followed by $\gamma$-Terpinene with $27.50 \%$ and o-Cymene with $\%$ 4.98 . 
ICAMS $2016-6^{\text {th }}$ International Conference on Advanced Materials and Systems

Table 4. The components and component ratios (\%) of the essential oil obtained from the leaves dried in a $30^{\circ} \mathrm{C}$ oven of the Thymbra spicata plant naturally growing in Hatay

\begin{tabular}{llll}
\hline RT & Compound Name & Cas \# & Area $\%$ \\
\hline 3,42 & $\alpha$-Pinene & $80-56-8$ & 0.27 \\
3,48 & $\alpha$-Thujene & $2867-05-2$ & 0.89 \\
4,78 & $\beta$-Pinene & $127-91-3$ & 0.07 \\
5,06 & Sabinene & $3387-41-5$ & 0.10 \\
6,04 & $\beta$-Myrcene & $123-35-3$ & 0.86 \\
6,39 & $\alpha$-Terpinene & $99-86-5$ & 1.77 \\
6,88 & Limonene & $5989-54-8$ & 0.13 \\
7,12 & $\beta$-Phellandrene & $555-10-2$ & 0.15 \\
8,22 & $\gamma$-Terpinene & $99-85-4$ & 27.50 \\
9 & o-Cymene & $527-84-4$ & 4.98 \\
15,42 & 1-Octen-3-ol & $3391-86-4$ & 0.08 \\
18,9 & trans Sabinene hydrate & $17699-16-0$ & 0.07 \\
20,39 & trans-Caryophyllene & $87-44-5$ & 1.09 \\
20,89 & Terpinen-4-ol & $562-74-3$ & 0.11 \\
24,47 & Isoborneol & $124-76-5$ & 0.08 \\
33,75 & Caryophyllene oxide & $1139-30-6$ & 0.20 \\
38,54 & $(-)-S p a t h u l e n o l$ & $77171-55-2$ & 0.21 \\
40,91 & Thymol & $89-83-8$ & 0.12 \\
41,7 & Carvacrol & $499-75-2$ & 60.33 \\
50,55 & Cyclohexene, 2-ethenyl-1,3,3-trimethyl- & $5293-90-3$ & 0.08 \\
\hline
\end{tabular}

\section{CONCLUSION}

The results of the study suggest that the highest ratio of carvacrol, the main component of Thymbra spicata essential oil is obtained from the fresh sample that was not dried $(72.54 \%)$. The highest carvacrol ratio was obtained in essential obtained from the leaves dried in a $30^{\circ} \mathrm{C}$ oven (\%60.33), this was followed by the essential obtained from shade-dried leaves (58.32\%) and sun-dried leaves (51.14\%). Thymbra spicata var. spicata both grows naturally and is cultivated in Hatay's flora and a study conducted to determine its essential oil components (Mert et al., 2007), it was found that the carvacrol ratio in the shade-dried leaves was $79.5 \%$ in samples harvested from the natural flora, and $80.6 \%$ in cultivated samples, and these walues vere higher than the carvacrol values that we obtained in shade-dried (58.32\%), fresn (72.54\%), sun-dried $(51.14 \%)$ and leaves dried in a $30^{\circ} \mathrm{C}$ oven.

\section{REFERENCES}

Dă̆ıstan E. and Sarıhan, E.O. (2009), Hatay line Özgü Bir Lezzet; Zahter. Türkiye VIII. Tarla Bitkileri Kongresi Poster Bildirileri, Hatay 269 - 273.

Kızıl, S., Özgüven, M. and Yamanoğlu, O. (2009), Önemli Bir Kekik Türü: Zahter. (Thymbra spicata L.var. spicata) Türkiye VIII. Tarla Bitkileri Kongresi. 19-22 Ekim 2009.Hatay, Cilt 1. Sunulu Bildiriler.s. 86-90.

Mert, A., Arslan, M. and Ayanoğlu, F. (2007), Hatay Florasında Doğal Olarak Yetişen Zahter (Thymbra spicata var. spicata) Uçucu Yağ çeriği, Yağ Bileşenleri ve Geleneksel Kullanımı. Türkiye VII. Tarla Bitkileri Kongresi 25-27 Haziran 2007. Erzurum (Poster Bildiri) 732 - 735.

Mert, A. and Türkmen, M. (2015), "The Effects of Drying Methods on the Essential Oil Content of Naturally Grown Thyme (Thymbra spicata) in Hatay Province", The 3rd International Symposium on Traditional Foods from Adriatic to Caucasus, 01-04 October 2015, Sarajevo/Bosna and Herzegovina Abstract Book, 335. 
Effects of Different Drying Methods on Components of Thymbra spicata L.

Essential Oil from Flora of Hatay (Turkey)

ב.

